\title{
Simulating Potential Weekly Stream and Pond Water Available for Irrigation in the Big Sunflower River Watershed of Mississippi Delta
}

\author{
Fei Gao ${ }^{1,2}$, Gary Feng ${ }^{3, *(\mathbb{D}}$, Ying Ouyang ${ }^{4}$, Johnie Jenkins ${ }^{3}{ }^{-1}$ and Changming Liu ${ }^{1,5}$ \\ 1 College of Water Sciences, Beijing Normal University, Beijing 100875, China; \\ gaofei@mail.bnu.edu.cn (F.G.); liucm@igsnrr.ac.cn (C.L.) \\ 2 Beijing Key Laboratory of Urban Hydrological Cycle and Sponge City Technology, Beijing 100875, China \\ 3 Genetics and Sustainable Agricultural Research Unit, United States Department of Agriculture-Agriculture \\ Research Service, Starkville, MS 39759, USA; Johnie.Jenkins@ars.usda.gov \\ 4 Center for Bottomland Hardwoods Research, USDA Forest Service, Starkville, MS 39762, USA; \\ youyang@fs.fed.us \\ 5 Institute of Geographical Sciences and Natural Resources Research, Chinese Academy of Sciences, \\ Beijing 100101, China \\ * Correspondence: gary.feng@ars.usda.gov; Tel.: +1-6623207449
}

Received: 19 April 2019; Accepted: 3 June 2019; Published: 18 June 2019

\begin{abstract}
Groundwater storage and level have declined rapidly in the Big Sunflower River Watershed (BSRW) of Mississippi Delta in recent years. Farmers in this region are beginning to save groundwater resources by increasing surface water usage for agricultural irrigation. In this study, we estimated the weekly amount of surface water available in ponds and streams, determined if the weekly surface water resources are sufficient for major crop irrigation demand, and assessed how much surface water can replace groundwater for agriculture irrigation in the BSRW. The SWAT (Soil and Water Assessment Tool) model was employed to simulate the weekly water resources for 23 sub-basins from the BSRW. Results showed that weekly stream water resources (SWR), stream evaporation (SE) and water loss from the channel via transmission through the side and bottom of the channel (stream transmission, referred as ST) for BSRW during the growing seasons ranged from 20.4 to $29.4 \mathrm{~mm}, 7.4$ to $14.4 \mathrm{~mm}$, 1.6 to $4.5 \mathrm{~mm}$ and 1.1 to $1.6 \mathrm{~mm}$, while pond water resources (PWR) and pond evaporation (PE) ranged from 1.9 to $2.1 \mathrm{~mm}$ and 0.3 to $0.5 \mathrm{~mm}$. The value of SWR - (ST + SE) and PWR - PE were positive in all sub-basins, indicating that there are net surface water resources available in this region. The percentages of total groundwater usage for irrigation that could be replaced by surface water in each sub-basin every week of each month from May to September ranged from $10 \%$ to $87 \%$. Our studies suggested that the conjunctive use of surface and groundwater for agriculture irrigation is a feasible method for groundwater sustainable management in the Mississippi Delta.
\end{abstract}

Keywords: Surface water resources; irrigation; stream; pond; SWAT model

\section{Introduction}

The Mississippi River alluvial plain in northwestern Mississippi (Mississippi Delta) is an important agricultural region in the United States with nearly $81 \%$ of the area being crop land including soybean, corn, cotton, and rice [1]. Although the average annual rainfall in this region is $1371 \mathrm{~mm}$, approximately $70 \%$ of the yearly rainfall occurs during the non-growing seasons, while only $30 \%$ of the annual rainfall occurs during the growing seasons [2-5]. Thus, nearly 7000 ha of the crop lands need supplemental irrigation [6]. However, irrigation relies largely on groundwater in this region, especially in the Big Sunflower River Watershed (BSRW) which is the most depleted aquifer in the Mississippi Delta [7]. 
According to Maupin and Barber [8], approximately $4.2 \times 10^{7} \mathrm{~m}^{3}$ per day of groundwater is withdrawn for irrigation from the Mississippi Delta aquifer. As a result, the groundwater level has decreased at least $12 \mathrm{~m}$ in the past 40 years [9]. Barlow and Clark [7] found that the groundwater level will continuously decline in the next 30 years if no water-use conservation practices are employed.

Steele et al. [10] indicated that rivers, streams and ponds are the alternate sources of irrigation water to groundwater. Phillips [11] reported that Mississippi has over 86,000 miles of rivers and streams in 10 major river basins including the BSRW. Furthermore, due to the shortage of groundwater resource, producers in the Mississippi Delta are beginning to realize the importance of reducing the groundwater use while increasing surface water usage in agricultural irrigation for mitigating groundwater resources depletion and sustaining irrigated agriculture [12].

Reducing groundwater use while increasing surface water usage may have benefits for irrigated agriculture. First of all, irrigation with surface water resources can greatly reduce pumping cost and stresses on the groundwater aquifer [12]. In addition, Stigter et al. [13] reported that irrigation with surface water keeps the groundwater table from declining continuously. Hence, in order to sustain irrigated agriculture, detailed information on regional available surface water resources for irrigation is crucial [14].

Recently, numerous hydrological models have been developed and applied to estimate the available amount of surface water for agriculture irrigation. Srivastava and Kalin [15] used the Soil and Water Assessment Tool (SWAT) to simulate the sustainable quantity of water withdrawn for irrigation from streams during the high flow periods in the southern state of Alabama, USA. Wu et al. [16] applied the GSFLOW [17] and DYCORS models [18] to optimize the conjunctive use of surface and groundwater for irrigation in Hei-he Basin, China. Tang et al. [5] employed the RZWQM2 model to simulate the weekly irrigation demand and rain water deficit in the Mississippi Delta. However, the amount of weekly available surface water for irrigation has not yet been determined. Therefore, it is imperative to determine whether or not the weekly surface water resources can meet the crop irrigation demand in the BSRW.

Additionally, although the aforementioned models have been widely applied and the acceptable results of the available amount of surface water resources for irrigation were obtained, some limitations to these models still exist. First of all, these models only regard the river discharge as irrigation sources without including pond resources, which is an important alternative source of water for crop irrigation [19]. In addition, stream transmission and stream and pond water evaporation are the major paths of water loss of surface water in a watershed [20,21]. However, these simulation studies have ignored stream transmission and stream and pond water evaporation. Thirdly, producers and growers often schedule their irrigation on a weekly basis; therefore, information on the weekly available amount of surface water for irrigation is crucial to the sustainable management of both ground and surface waters $[5,22]$. However, few studies have been conducted to determine potential surface water availability on a weekly time scale. Previous studies are more focused on annual and monthly surface water resources in other regions. Therefore, it is necessary to estimate the weekly available amount of surface water in streams and ponds for irrigation using a hydrological model.

The Soil and Water Assessment Tool model (SWAT) was developed for simulating comprehensive hydrological process by combining the land surface and stream hydrologic processes [23]. The reasons for applying the SWAT model in this study were: (1) the river flow rate and volume in each sub-basin can be simulated by Manning's equation, and ponds volume can be calculated by the pond water balance equation in SWAT [24]; (2) water loss through stream transmission and evaporation can be simulated on a daily basis in each sub-basin and then summed to weekly scale. Such advantages indicated that SWAT is capable of determining the available weekly surface water resources.

Weekly data of surface water resources available for irrigation are needed to address water scarcity in BSRW; however, those data are not available in this region. The objectives of this study were to: (1) estimate weekly available amount of surface water in ponds and streams and determine whether 
the weekly surface water resources are enough to meet irrigation demand of major crops in BSRW; and (2) determine how much surface water can replace groundwater for agriculture irrigation in the BSRW.

\section{Materials and Method}

\subsection{Study Area}

The BSRW is located in the center of the Mississippi Delta, in Mississippi, USA, between latitudes $31^{\circ}$ and $35^{\circ}$ north and longitudes $91^{\circ}$ and $92^{\circ}$ east (Figure 1 ). BSRW covers an area of approximately $10,877 \mathrm{~km}^{2}[25,26]$. BSRW is classified as a humid subtropical climate with an average annual rainfall of $1300 \mathrm{~mm}$, annual evapotranspiration of $800 \mathrm{~mm}$, and average temperature of 18. More information on climate data can be seen in Table 1. Composed of fertile soils, long growing seasons and high average annual rainfall, this region is an important crop production area in Mississippi, and mainly includes soybean, corn, rice and cotton, which account for over $80 \%$ of the total land use area in this watershed [25,27]. Parajuli and Jayakody [26] reported that there are 11 rivers located in the Big Sunflower River Watershed, and the major river is Big Sunflower River which had a drainage area of approximately 280 to $6733 \mathrm{~km}^{2}$ [25]. Ouyang [19] also reported that some farm ponds have been built over the past years for agriculture irrigation due to the dramatic decline in the groundwater table.

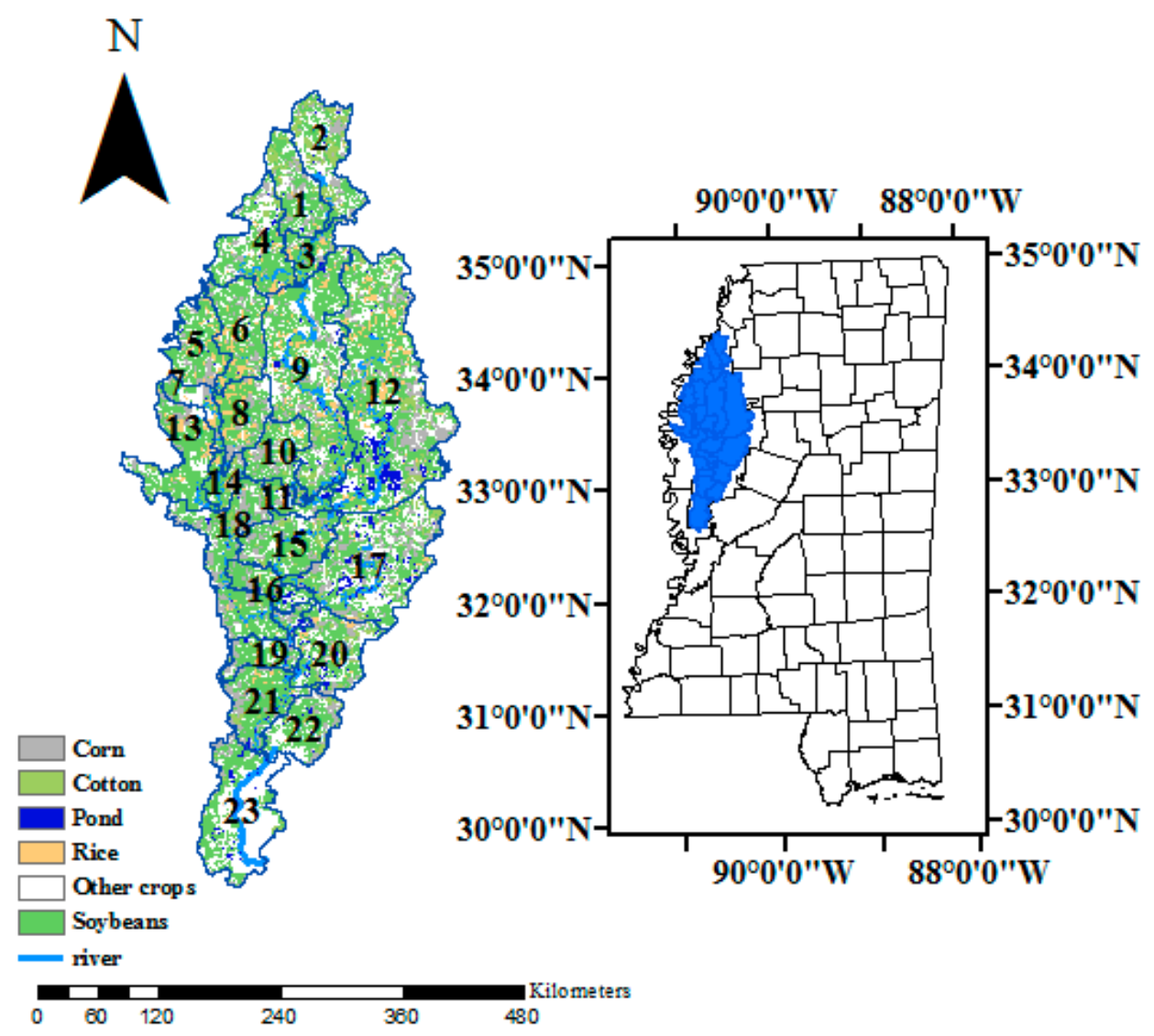

Figure 1. Location of study area and land use in Big Sunflower River Watershed. 
Table 1. Monthly weather data in Big Sunflower River Watershed.

\begin{tabular}{ccccc}
\hline Month & $\begin{array}{c}\text { Rainfall } \\
(\mathbf{m m})\end{array}$ & $\begin{array}{c}\text { Maximum } \\
\text { Temperature }\left({ }^{\circ} \mathbf{C}\right)\end{array}$ & $\begin{array}{c}\text { Maximum } \\
\text { Temperature }\left({ }^{\circ} \mathbf{C}\right)\end{array}$ & Humidty \\
\hline January & 130 & 13 & 2 & $76 \%$ \\
February & 133 & 15 & 3 & $75 \%$ \\
March & 144 & 20 & 7 & $71 \%$ \\
April & 136 & 25 & 12 & $68 \%$ \\
May & 127 & 29 & 17 & $69 \%$ \\
June & 98 & 32 & 20 & $70 \%$ \\
July & 106 & 34 & 22 & $73 \%$ \\
August & 82 & 33 & 21 & $70 \%$ \\
September & 85 & 31 & 18 & $68 \%$ \\
October & 97 & 26 & 12 & $69 \%$ \\
November & 116 & 19 & 6 & $73 \%$ \\
December & 149 & 14 & 3 & $77 \%$ \\
\hline
\end{tabular}

\subsection{SWAT Model}

In a previous study, Dakhlalla et al. [27] successfully utilized the SWAT model in the Big Sunflower River Watershed. The inputs required by SWAT are digital elevation model (DEM), land use data, soil properties, and weather data. The DEM was obtained from United States Geological Survey (USGS) (https://viewer.nationalmap.gov/basic/). The land use data in 2016 can be found from United States Department of Agriculture-National Agriculture Statistics Service (NASS) (https://nassgeodata.gmu.edu/CropScape). Soil data were downloaded from Natural Resources Conservation Service of the United States Department of Agriculture (NRCS) (https://www.nrcs. usda.gov/wps/portal/nrcs/main/ms/soils/surveys/), and weather data (daily maximum and minimum air temperatures, solar radiation, relative humidity, and wind speed) between 2000 and 2016 were obtained from the NRCS SSURGO database. The Big Sunflower River Watershed was divided into 23 sub-basins by the digital elevation model. The parameters required by the model related to this study were calibrated and validated using the observed data of streamflow and groundwater level [27]. The performance of the SWAT was acceptable and thus the calibrated and validated SWAT model was applied in this study for determining the weekly potential amount of surface water available for irrigation. One of the objectives of this study is to quantify the available weekly surface water resources for irrigation. The previous study has already calibrated and validated the SWAT model by using the streamflow data and ET data; therefore, SWAT can be used to estimate surface water resources (include water in stream and pond).

\subsection{Definition of Surface Water Resources and Water Loss}

The SWAT model assumes that the stream channels have a trapezoidal shape, and the volume of stream water held in the channel and can be calculated as [23]:

$$
V_{\text {stream }}=1000 \cdot A_{\text {stream }} \cdot L_{\text {stream }}
$$

The stream water resources (SWR) in each sub-basin can be simulated as [23]:

$$
S W R=\frac{V_{\text {stream }}}{A_{\text {subba } \sin }}
$$

In the SWAT model, ponds are defined as the water bodies that are located within sub-basins, and the volume of pond water resources $(P W R)$ can be calculated as [23]:

$$
V_{\text {pond }}=V_{\text {stored }}+V_{\text {flowin }}-V_{\text {flowout }}+V_{\text {pcp }}-V_{\text {evap }}-V_{\text {seep }}
$$




$$
P W R=\frac{V_{\text {pond }}}{A_{\text {subbasin }}}
$$

where $V_{\text {pond }}$ is the volume of pond water at the end of the day $\left(\mathrm{m}^{3}\right) ; V_{\text {stored }}$ is the volume of water stored in the pond water body at the beginning of the day $\left(\mathrm{m}^{3}\right) ; V_{\text {flowin }}$ is the volume of pond water entering the water body during the day $\left(\mathrm{m}^{3}\right) ; V_{\text {flowout }}$ is the volume of pond water flowing out of the water body during the day $\left(\mathrm{m}^{3}\right) ; V_{p c p}$ is the volume of precipitation falling on the pond water body during the day; $V_{\text {evap }}$ is the volume of water removed from the pond water body by evaporation during the day $\left(\mathrm{m}^{3}\right)$; $V_{\text {seep }}$ is the volume of water lost from the pond water body by seepage $\left(\mathrm{m}^{3}\right)$; Depth pond water during the day in each sub-basin; and $S A_{\text {pond }}$ is the surface area of the pond water.

The stream transmission (ST) is the water loss from the channel via transmission through the side and bottom of the channel. Stream evaporation $(S E)$ was defined as the water losses from stream by evaporation; pond evaporation (PE) was defined as the water loss from pond by evaporation. $S T, S E$ and $P E$ can be calculated by [23]:

$$
\begin{gathered}
S T=K_{c h} \cdot T T \cdot P_{c h} \cdot L_{c h} \\
S E=\operatorname{coe} f_{e v} E_{0} L_{c h} W_{f r \Delta t} \\
P E=10 \cdot \eta \cdot E_{0} \cdot S A
\end{gathered}
$$

where ST is the channel transmission losses $\left(\mathrm{m}^{3}\right), K_{c h}$ is the effective hydraulic conductivity of the channel alluvium $\left(\mathrm{mm} \mathrm{h}^{-1}\right), T T$ is the flow travel time $(\mathrm{h}), \mathrm{P}_{\mathrm{ch}}$ is the wetted perimeter $(\mathrm{m})$, and $L_{c h}$ is the channel length $(\mathrm{km})$; $S E$ is the evaporation from the reach for the day $\left(\mathrm{m}^{3}\right)$, coef $f_{e v}$ is an evaporation coefficient, $E_{0}$ is the potential evaporation $(\mathrm{mm}), W$ is the channel width at water level $(\mathrm{m})$, and $f r_{\Delta \mathrm{t}}$ is the fraction of the time step in which water is flowing in the channel; $P E$ is the volume of water removed from the pond body by evaporation, $\eta$ is an evaporation coefficient, and $S A$ is the surface area of the pond body.

As discussed above, stream water resources potential (SWRP) is defined as: $S W R P=S W R$ - $(S E+S T)$; Pond water resources potential $($ PWRP) was defined as: PWRP $=$ PWR - PE. Many studies reported that maintaining environmental flow plays a critical role in protecting rivers and their ecosystems [28-30]. In other words, the minimum water flow and level must be maintained in streams to prevent harm to aquatic ecosystems and wetlands [31,32]. Currently, no effort has been devoted to developing the suitable environmental flow for the streams in the BSRW. Ouyang [31] developed an approach for low stream flow selection in Mississippi and Florida, USA. Based on the flow duration curve calculation, this author found that the low stream flow can be selected when the percentage of stream discharge equals to or exceeds $80 \%$ for the purpose of preventing ecosystem from degradation. Based on this finding and postulating that the stream water flow and stream water volume are somewhat proportional to each other, we assumed that the stream water cannot be used more than $80 \%$ at any time although further study is warranted to develop a suitable environmental flow for this watershed. Therefore, available surface water resources potential (ASWR) were defined as ASWR $=80 \%$ SWRP + PWRP. The percentage of groundwater use for irrigation that could be replaced by surface water $\left(\mathrm{P}_{\mathrm{gs}}\right)$ was defined as: $\mathrm{P}_{\mathrm{gs}}=\mathrm{ASWR} /$ irrigation demand.

\subsection{Irrigation Demand}

The irrigation requirements for soybean, corn and cotton were obtained from Tang et al. [5]. Tang et al. [5] employed the RZWQM2 model and determined the irrigation demand of soybean, corn and cotton taking into consideration weather conditions in the previous 100 years in the Mississippi Delta. Their results of weekly irrigation demand of the three crops were compiled and summarized in Table 2. The rice required irrigation amount was obtained from Yazoo Mississippi Delta Joint Water Management District [33]. 
Table 2. Weekly irrigation demands for soybean, corn, cotton, and rice during growing season in Big Sunflower River Watershed.

\begin{tabular}{|c|c|c|c|c|c|}
\hline \multirow{2}{*}{ Month } & \multicolumn{5}{|c|}{ Irrigation Demand (mm) } \\
\hline & Weeks & Soybean & Corn & Cotton & Rice \\
\hline \multirow{2}{*}{ May } & 19 & - & 1.4 & - & 76.3 \\
\hline & 20 & - & 10.1 & - & 76.3 \\
\hline \multirow{4}{*}{ June } & 21 & - & 14.5 & - & 91.5 \\
\hline & 22 & - & 19.6 & - & 91.5 \\
\hline & 23 & 3.6 & 25.4 & - & 91.5 \\
\hline & 24 & 12.8 & 23.6 & - & 91.5 \\
\hline \multirow{4}{*}{ July } & 25 & 21.9 & 23.7 & - & 84.0 \\
\hline & 26 & 22.3 & 21.2 & - & 84.0 \\
\hline & 27 & 25.4 & 25.7 & 8.6 & 84.0 \\
\hline & 28 & 24.6 & 20.3 & 8.1 & 84.0 \\
\hline \multirow{4}{*}{ August } & 29 & 24.4 & 22.7 & 14.3 & 7.5 \\
\hline & 30 & 23.2 & 16.9 & 15.3 & 7.5 \\
\hline & 31 & 29.3 & 21.9 & 27.1 & 7.5 \\
\hline & 32 & 26.6 & 14.1 & 24.4 & 7.5 \\
\hline \multirow{4}{*}{ September } & 33 & 25.6 & 10.6 & 29.2 & - \\
\hline & 34 & 27.9 & 4.7 & 29.6 & - \\
\hline & 35 & 15.1 & - & 19.0 & - \\
\hline & 36 & 12.1 & - & 23.0 & - \\
\hline \multirow{6}{*}{ October } & 37 & - & - & 15.1 & - \\
\hline & 38 & - & - & 11.2 & - \\
\hline & 39 & - & - & 15.0 & - \\
\hline & 40 & - & - & 14.1 & - \\
\hline & 41 & - & - & 9.0 & - \\
\hline & 42 & - & - & 8.5 & - \\
\hline
\end{tabular}

\section{Results and Discussion}

\subsection{Weekly SWRP and WPRP}

Weekly rainfall, SWR, PWR, SE, ST, and PE for BSRW from April to October is shown in Figure 2. Rainfall, SWR, SE, and ST ranged from 20.4 to $29.4 \mathrm{~mm}, 7.4$ to $14.4 \mathrm{~mm}, 1.6$ to $4.5 \mathrm{~mm}$, and 1.1 to $1.6 \mathrm{~mm}$, respectively. PWR and PE ranged from 1.9 to $2.1 \mathrm{~mm}$ and 0.3 to $0.5 \mathrm{~mm}$. Our results indicated that weekly SWR were higher in April, May and October than in the other months. This might be caused by the relatively higher rainfall in April, May and October. Figures 3 and 4 showed averaged weekly SWRP and PWRP in each sub-basin from April to October in BSRW. In April (Figure 3a) and May (Figure $3 \mathrm{~b}$ ), the average weekly SWRP for the entire BSRW were 8.0 and $8.3 \mathrm{~mm}$, but decreased to $4.8 \mathrm{~mm}$ in June (Figure 3c) and July (Figure 3d); with the coming month of August (Figure 3e), SWRP had been reduced to the lowest value of $4.7 \mathrm{~mm}$. However, the average weekly SWRP for the entire BSRW has increased to $7.9 \mathrm{~mm}$ in October (Figure 3g). Figure $4 \mathrm{~h}$ also showed that the average weekly PWRP of each sub-basins during the growing season ranged from 0.2 to $5.3 \mathrm{~mm}$, of which the three highest values were obtained in sub-basin $17(4.1 \mathrm{~mm}), 15(4.4 \mathrm{~mm})$ and $23(5.3 \mathrm{~mm})$, while the three lowest value were obtained in sub-basin $4(0.2 \mathrm{~mm})$, sub-basin $7(0.6 \mathrm{~mm})$ and sub-basin 2, $20(0.7 \mathrm{~mm})$. In general, SWRP and PWRP differ by sub-basins and month; this might be caused by the amount of irrigation caused by the landuse in each sub-basin. In sub-basin 1 to 13 , the area of rice accounted for nearly $70 \%$ of the total rice area in BSRW, which consumes much more water for irrigation, therefore, SWRP and PWRP were less in these sub-basins. Our results indicated that the values of SWRP and PWRP are positive and there was net surface water available in this region. 


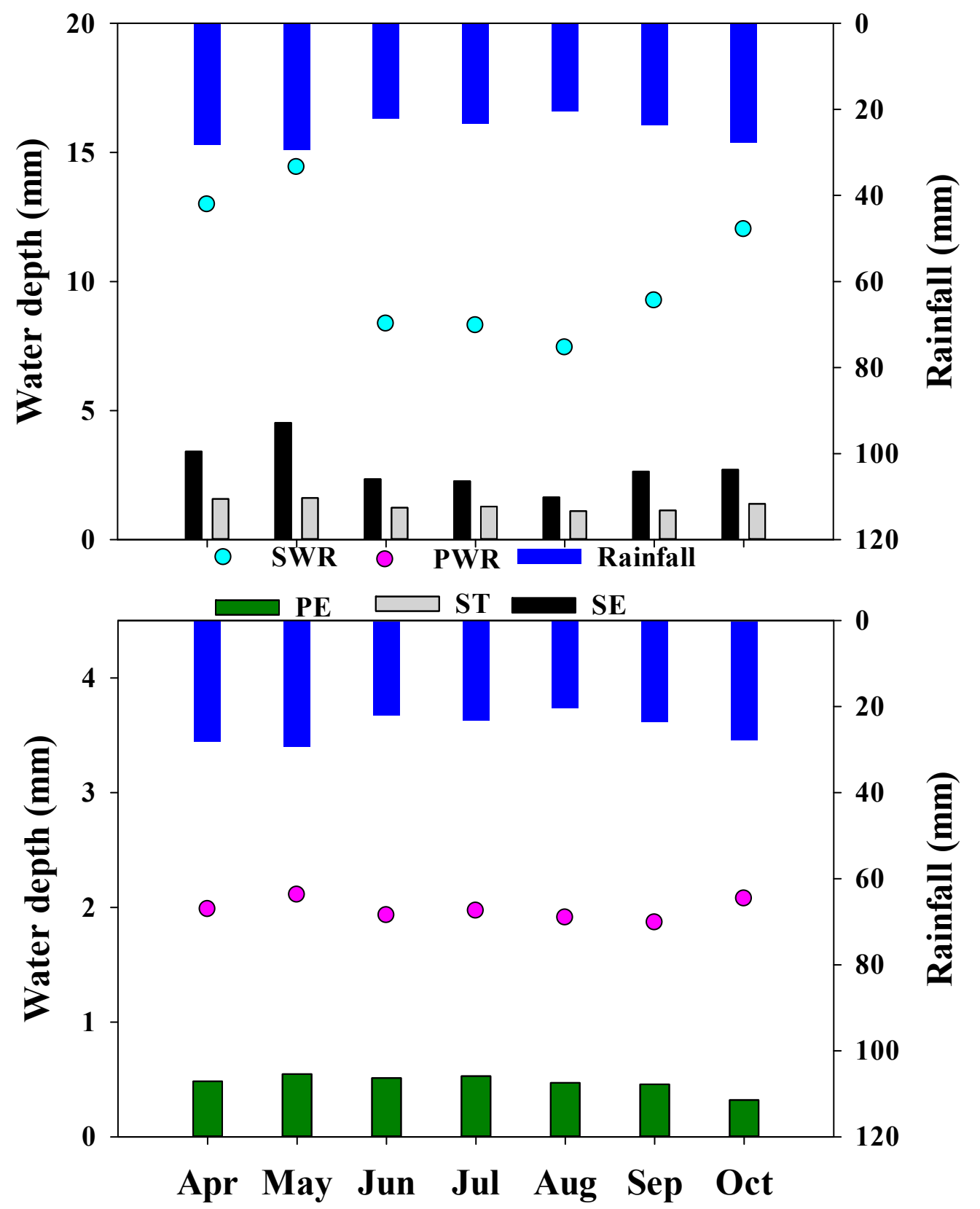

Figure 2. Weekly rainfall, stream water resources (SWR), stream evaporation (SE) and stream transmission (ST), pond water resources (PWR), and pond water evaporation (PE) from April to October in Big Sunflower River Watershed. 

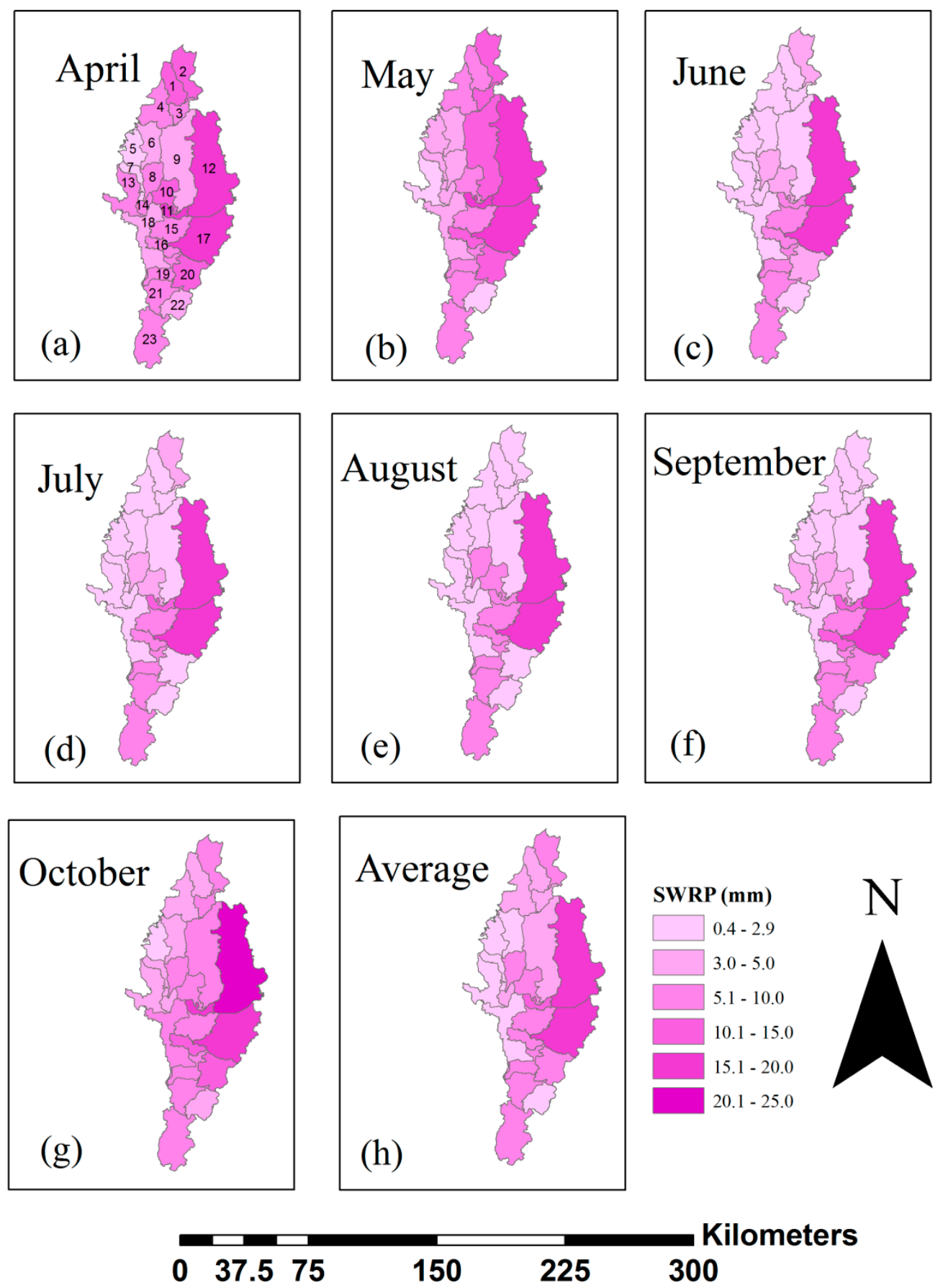

\section{0}

\section{5}

Kilometers

Figure 3. Spatial distribution of simulated weekly stream water resources potential (SWRP) in each sub-basin during crop growing season between 2000 and 2016. ${ }^{*}$ SWRP is defined as: SWRP = SWR - (SE + ST); SWR is stream water resources (SWR); SE is stream water evaporation; and ST is stream transmission. 

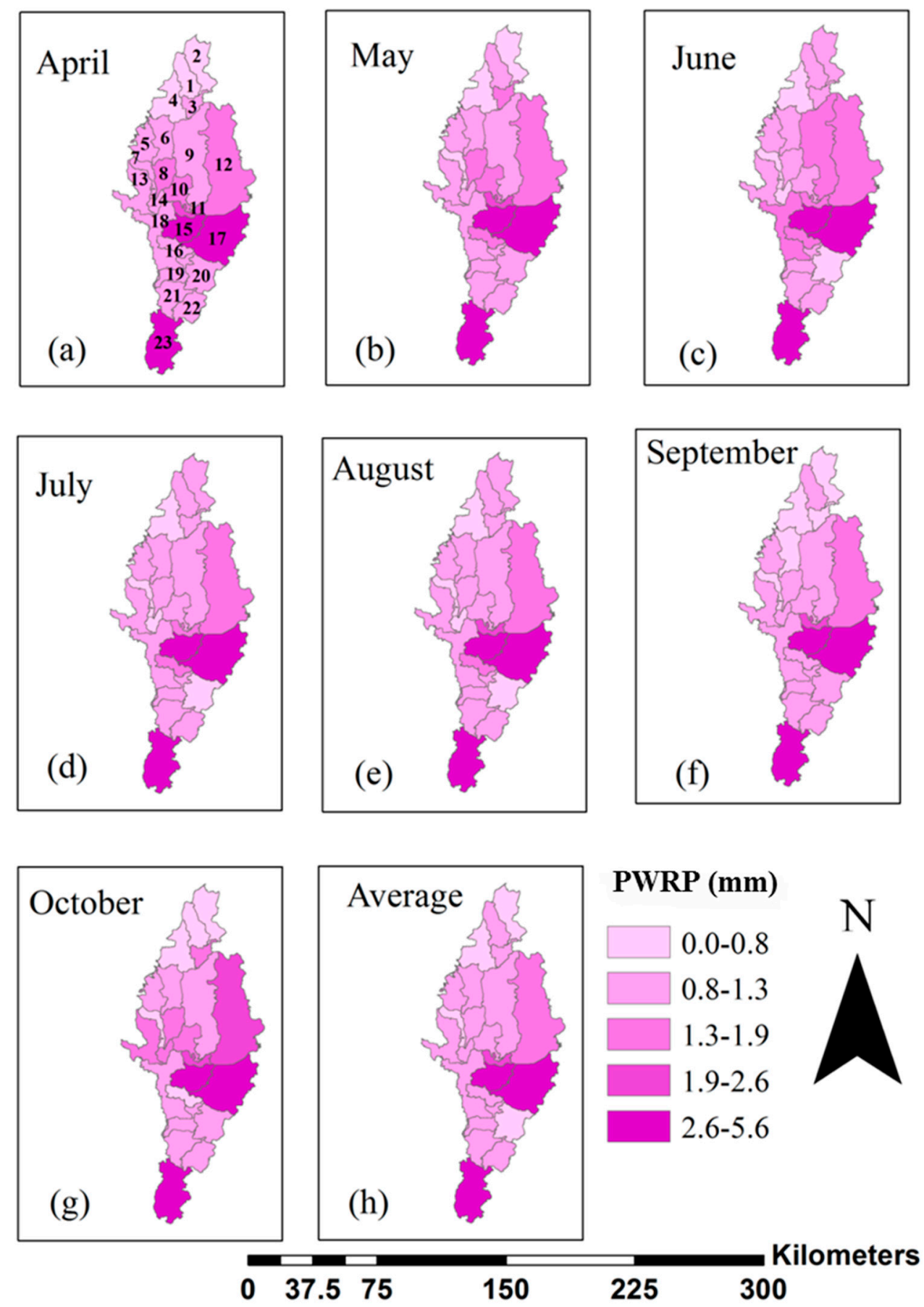

Figure 4. Spatial distribution of simulated weekly pond surface water resources potential (PWRP) in each sub-basin during the growing season between 2000 and 2016. ${ }^{*}$ PWRP is defined as: PWRP $=$ PWR - PE; PWR is pond water resources; PE is pond water evaporation.

\subsection{Weekly Available ASWR for Irrigation}

Based on the assumption made by Ouyang [31], weekly ASWR, rainfall and irrigation demand for soybean, corn, cotton and rice production in each sub-basin from May to October in BSRW are displayed in Figure 5. In general, weekly ASWR in each sub-basin was not sufficient to meet the weekly total irrigation demands from May to September. The weekly ASWR of each sub-basin in each month ranged from 0.3 to $18.6 \mathrm{~mm}$ with an average value of $5.9 \mathrm{~mm}$, while the weekly total irrigation demands ranged from 53 to $138.6 \mathrm{~mm}$. Zhang et al. [34] reported that rainfall has significant influences 
on crop productions in Mississippi since it is variable from year-to-year during crop-growing seasons (Paz et al., 2007). We also made comparisons between weekly irrigation demands and the ASWR + rainfall (ASWRR) (Figure 5). The weekly ASWRR of each sub-basin from May to September ranged 11.6 to $55.9 \mathrm{~mm}$, while weekly total irrigation demands ranged from 53 to $138.6 \mathrm{~mm}$. It showed that there were deficits between weekly total irrigation demands and ASWRR, which ranged from 6.9 to $124.5 \mathrm{~mm}$. Averaged by sub-basins, the weekly ASWRR were $37.5 \mathrm{~mm}$ in May, $27.3 \mathrm{~mm}$ in June, $28.5 \mathrm{~mm}$ in July, $25.6 \mathrm{~mm}$ in August, and $29.4 \mathrm{~mm}$ in September; and the deficits between total weekly irrigation demands and ASWRR were $44.5 \mathrm{~mm}$ in May, $93.2 \mathrm{~mm}$ in June, $110.1 \mathrm{~mm}$ in July, $47 \mathrm{~mm}$ in August, and $23.6 \mathrm{~mm}$ in September. Averaged by months, the deficits between weekly ASWRR and total irrigation demands ranged from 47.3 to $76.5 \mathrm{~mm}$. Many researchers indicated that land use change may influence the surface water storage [35-38], and the surface water scarcity could be alleviated if reasonable land use alteration strategies were applied [39,40]. It is obvious that weekly surface water resources are not sufficient to satisfy the rice irrigation demands. Therefore, six different land use scenarios were set to find the best solution for alleviating the surface water scarcity. These scenarios include only planting soybean (scenario1, area for soybean is $6742 \mathrm{~km}^{2}$ ), only planting corn (scenario 2, area for corn is $6742 \mathrm{~km}^{2}$ ), only planting cotton (scenario 3, area for cotton is $6742 \mathrm{~km}^{2}$ ), planting soybean and corn (scenario $4,3371 \mathrm{~km}^{2}$ for soybean and $3371 \mathrm{~km}^{2}$ for corn), planting soybean and cotton (scenario $5,3371 \mathrm{~km}^{2}$ for soybean and $3371 \mathrm{~km}^{2}$ for cotton), and planting corn and cotton (scenario 6, $3371 \mathrm{~km}^{2}$ for corn and $3371 \mathrm{~km}^{2}$ for cotton). Figure 6 showed the relationship between crop irrigation demands and the ASWRR under six different land use scenarios. Figure 6 indicated that the crop irrigation demands can be satisfied during the growing seasons if scenario 1 (except in August), scenario 2 and scenario 3 are employed individually in BSRW. Figure 6 also showed that ASWRR does not satisfy the irrigation demands if scenario 4, scenario 5 and scenario 6 are employed in BSRW. Compared to other scenarios, scenario 6 (corn and cotton) needs less surface water resources to satisfy the irrigation demands since only $2.5 \mathrm{~mm}(\mathrm{Jul}), 13.6 \mathrm{~mm}$ (Aug) and 3.4 (Sep) of irrigation water are needed. Therefore, scenario 1 , scenario 2 , scenario 3 , and scenario 6 were suggested to employ in BSRW.
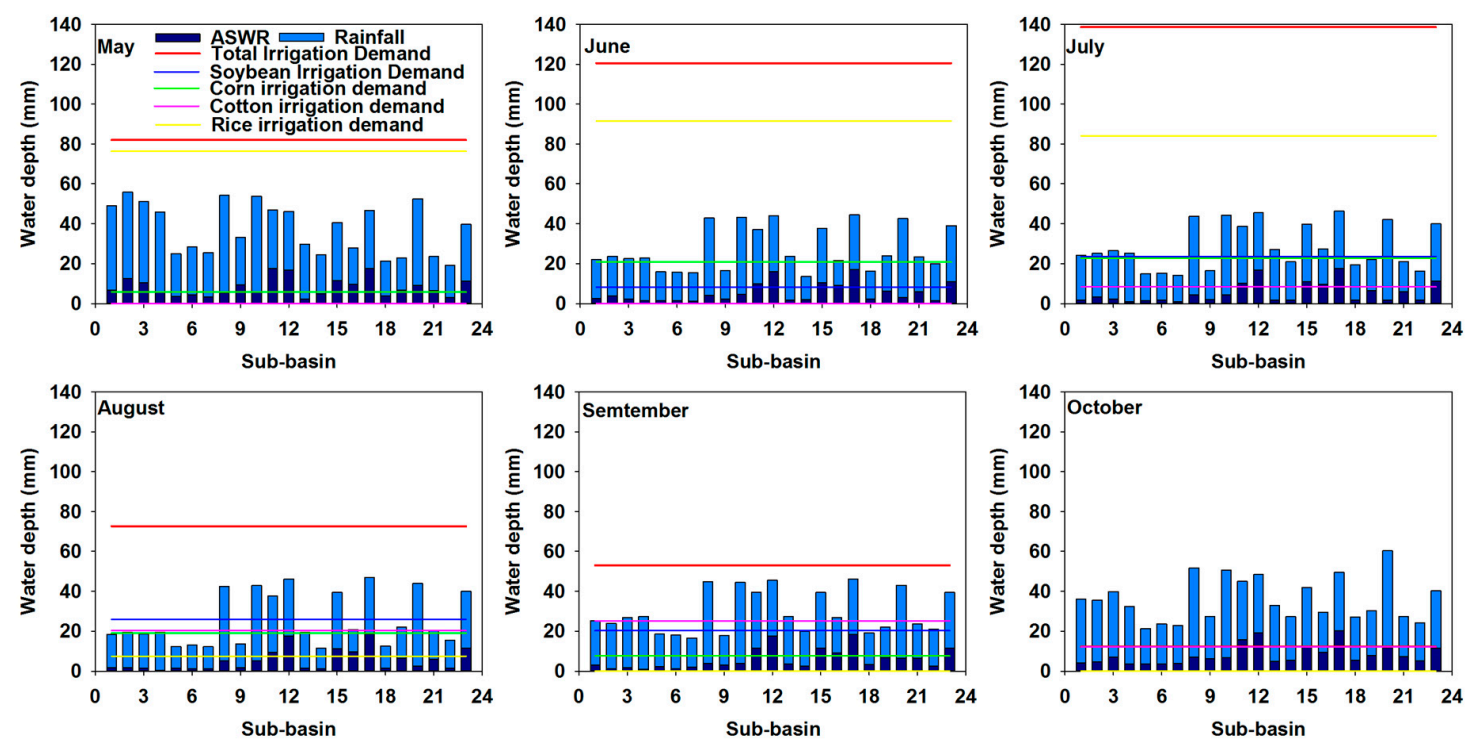

Figure 5. Comparisons between averaged weekly available surface water potential (ASWR) and weekly irrigation demands for soybean, corn, cotton, and rice in each subbasin from May to October in Big Sunflower River Watershed. * ASWR is defined as: ASWR $=80 \%$ SWRP + PWRP; SWRP is defined as: $\mathrm{SWRP}=\mathrm{SWR}-(\mathrm{SE}+\mathrm{ST})$; SWR is stream water resources, $\mathrm{SE}$ is stream water evaporation, $\mathrm{ST}$ is stream transmission; PWRP is defined as: PWRP = PWR - PE; PWR is pond water resources, PE is pond water evaporation. 

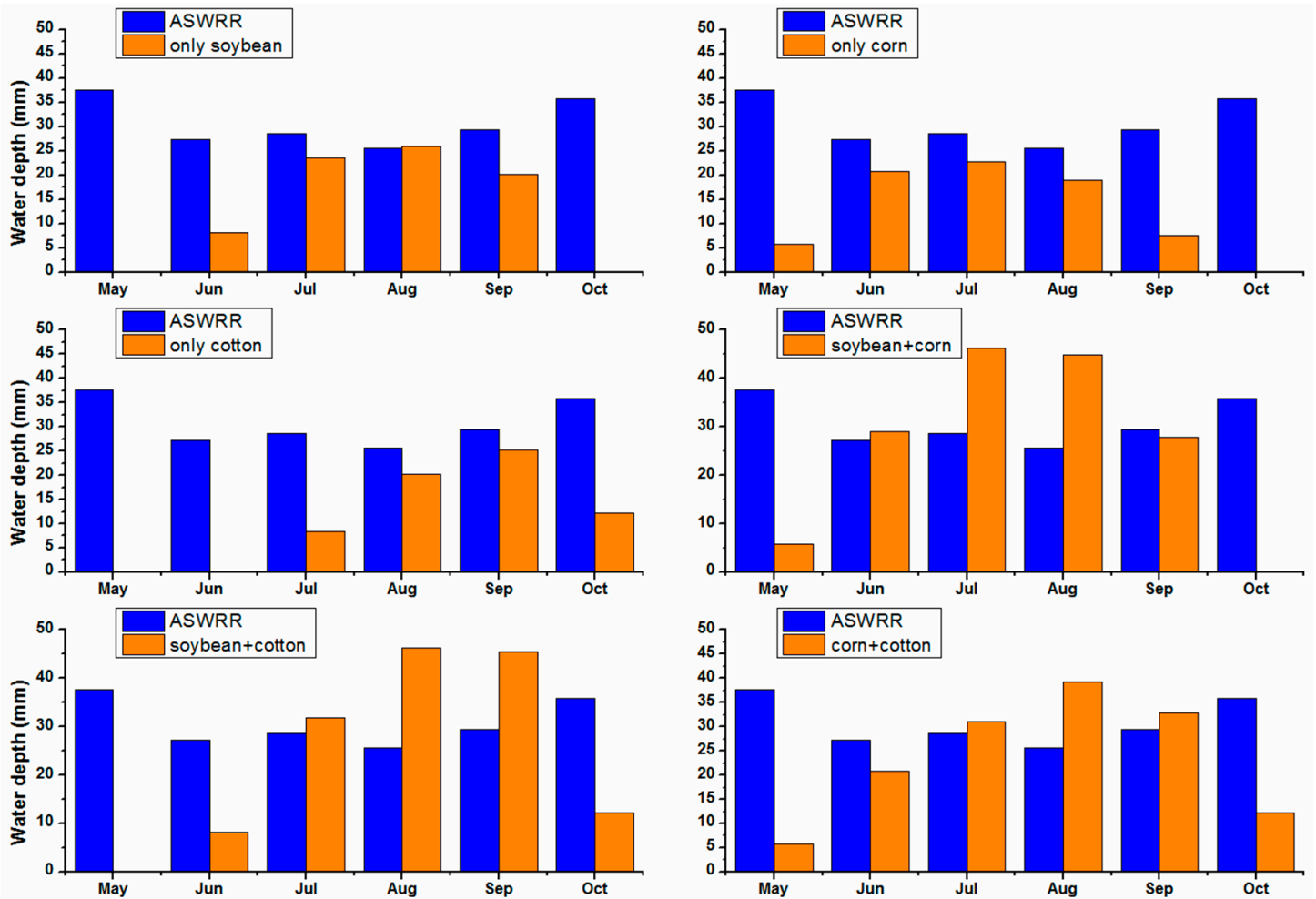

Figure 6. The relationship between crop irrigation demands and the sum of ASWR and rainfall under six different land use scenarios. * ASWR is defined as: ASWR $=80 \%$ SWRP + PWRP; SWRP is defined as: $\mathrm{SWRP}=\mathrm{SWR}-(\mathrm{SE}+\mathrm{ST})$; SWR is stream water resources, SE is stream water evaporation, $\mathrm{ST}$ is stream transmission; PWRP is defined as: PWRP = PWR - PE; PWR is pond water resources; PE is pond water evaporation.

\subsection{Potential Available Amount of Surface Water as An Alternative to Groundwater for Irrigation}

Figure 7 shows the percent of weekly groundwater use for irrigation that could be replaced by surface water $\left(\mathrm{P}_{\mathrm{gs}}\right)$ in each sub-basin every month. In general, the $\mathrm{P}_{\mathrm{gs}}$ of each sub-basin ranged from $10 \%$ to $87 \%$ from May to September. Our results indicated that there was potential to reduce the groundwater use in BSRW if weekly ASWRR were used for irrigation. The average $P_{g s}$ for the entire BSRW were $46 \%$ in May, 23\% in June, $21 \%$ in July, 35\% in August, and 56\% in September. Although the surface water resources were not sufficient for maintain the irrigation demands in BSRW (Figure 5), it can be used as an alternative irrigation source for reducing the groundwater use. Reducing groundwater pumping and increasing surface water use for irrigation might be a sustainable way to mitigate the intensity of groundwater use stress [41]. Bredehoeft and Young [42] also reported that conjunctive use of surface and groundwater for agriculture irrigation is a practical strategy for sustainable groundwater planning and management. Therefore, conjunctive use of both surface and groundwater might be a solution to mitigate water resources scarcity. Butler et al. [43] developed a new and simple water balance model to assess the future trend of the aquifer of Kansas over the short and medium term and found that a reduction in annual pumping of $22 \%$ groundwater can maintain the annual averaged groundwater level. Barow and Clark [9] employed the MODFLOW model to simulate the effectiveness of different groundwater conservation scenarios in maintaining the groundwater level in Mississippi Delta. They found that a $25 \%$ reduction of groundwater use resulted in the greatest increase in groundwater storage. However, these results resulted from reduction scenarios on an annual basis, which is not able to meet growers' needs for scheduling irrigation on a weekly basis [22]. Our results were calculated on a weekly basis for each sub-basin in BSRW, which is helpful for farmers to schedule their irrigation strategy. In addition, these research results were obtained for the entire watershed; they are not accurate enough to aid irrigation scheduling for growers in each sub-basin. 
Therefore, farmers in different sub-basins can use our results to make a decision on how much surface and groundwater will be used for irrigation during the growing seasons.
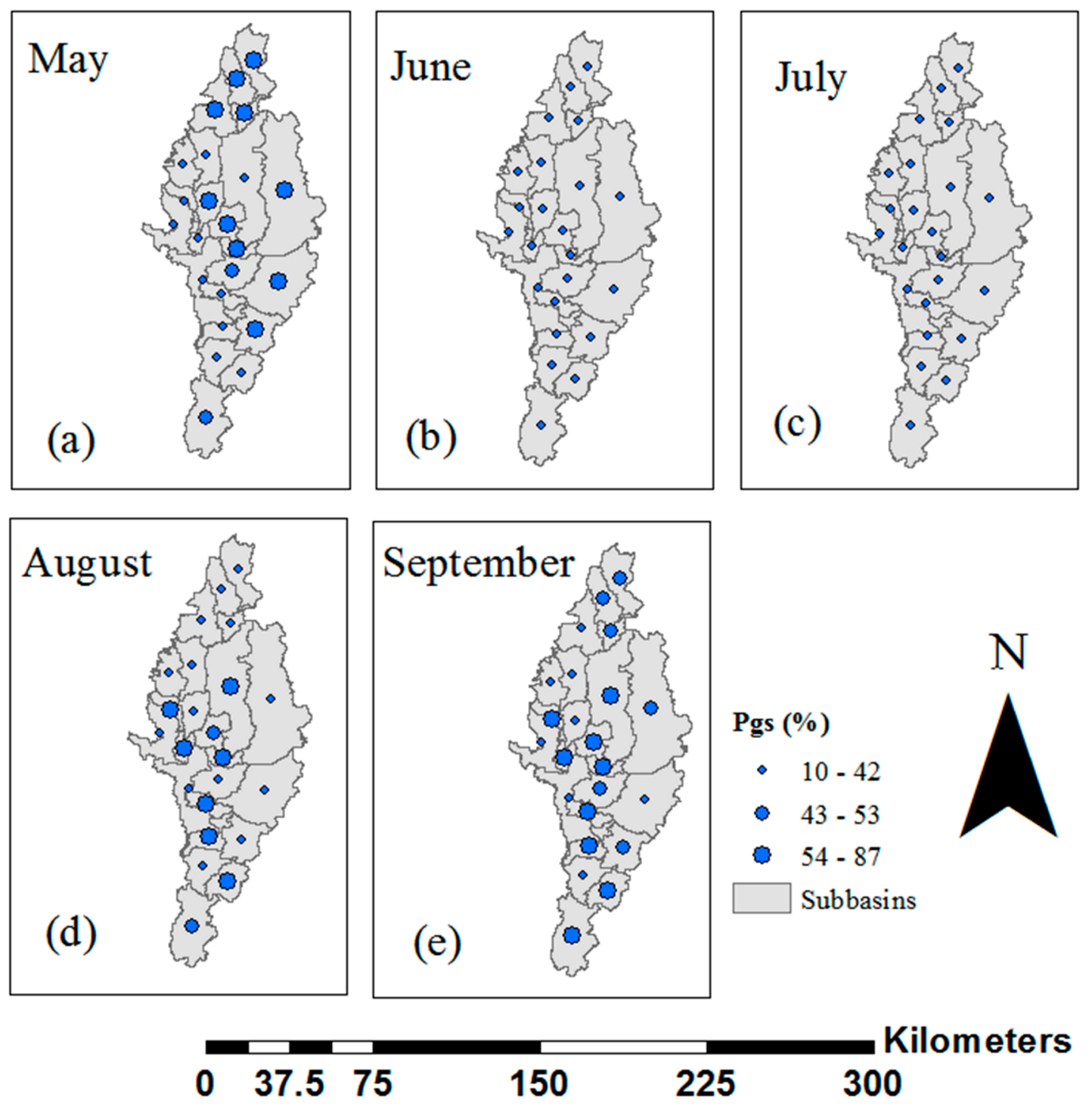

\section{0}

225

Kilometers

Figure 7. Percentage between weekly available surface water $\left(\mathrm{P}_{\mathrm{gs}}\right)$ for irrigation and total irrigation requirement, averaged all weeks of each month in Big Sunflower River Watershed. * $\mathrm{P}_{\text {gs }}$ was defined as: $\mathrm{P}_{\mathrm{gs}}=\mathrm{ASWR} /$ total irrigation demands; ${ }^{*}$ ASWR is defined as: ASWR $=80 \%$ SWRP + PWRP; SWRP is defined as: SWRP = SWR - (SE + ST), SWR is stream water resources, SE is stream water evaporation, $\mathrm{ST}$ is stream transmission; PWRP is defined as: $\mathrm{PWRP}=\mathrm{PWR}-\mathrm{PE}$; PWR is pond water resources, $\mathrm{PE}$ is pond water evaporation.

\section{Conclusions}

Detailed knowledge about available surface water resources for irrigation is critical for sustainable water resources management in BSRW where groundwater resources are under increasing pressure. Despite the importance of surface water resources, only a few studies related to this subject have been performed. Most of the studies estimate surface water resources on an annual time scale which is not practical for farmers to schedule their irrigation strategies. In this study, the SWAT model was applied to estimate the weekly potential available amount of water in streams and ponds for irrigation in BSRW based on the assumption of the environmental flow concept. We also determine the percent of groundwater use for irrigation that was replaced by surface water resources in BSRW. 
Our results demonstrated that weekly stream water resources (SWR) and pond water resources (PWR) in BSRW ranged from 20.4 to $29.4 \mathrm{~mm}$ and 1.9 to $2.1 \mathrm{~mm}$, which were higher than its water loss (stream transmission, stream evaporation and pond evaporation) during the growing seasons (from April to October). Although the weekly total amount of available surface water resources potential (ASWR) and rainfall were not sufficient to meet the weekly total irrigation demands during growing seasons, the amounts of weekly groundwater use for irrigation that could be replaced by surface water (Pgs) were $46 \%$ in May, 23\% in June, 21\% in July, 35\% in August, and 56\% in September.

There was potential to reduce the groundwater use in BSRW by using surface water resources. Our study also concluded that land use changes and using combinations of surface and groundwater might be two solutions to mitigate the depletion of groundwater use in BSRW. Our results suggested that surface water resources would be sufficient for crop productions in BSRW if we only plant soybean, corn, and cotton individually or plant corn and cotton combinations in BSRW. The ideas, models, and approaches demonstrated in this research could be applied to other regions of the world which face great challenges as the groundwater level continues to decline. The main finding of this study, is that if farmers reduce the planting areas of rice, this could reduce the amount of irrigation water, which would be helpful for groundwater resources management. The limitation of this study is that the groundwater flow model was not used to simulate the groundwater recharge which is very important for driving the SWAT model to simulate the interactions between surface and groundwater; therefore, this model should be used in future studies.

Author Contributions: Model application, data analysis, original draft and revision, F.G.; supervision, conceptualization, methodology, writing - review, revision and editing, G.F.; editing, J.J., provided professional guidance, C.L.; performed the stream minimum flow data collection, Y.O.

Funding: This research was funded by China Scholarship Council (No. 201606040138) and Mississippi Soybean Promotion Board (62-2019).

Acknowledgments: This work was completed in the Genetics and Sustainable Agriculture Research Unit, USDA-ARS as a visiting Ph.D candidate sponsored by the China Scholarship Council (No. 201606040138) and Mississippi Soybean Promotion Board (62-2019).

Conflicts of Interest: The authors declare no conflict of interest.

\section{References}

1. Economic Research Service, U.S. Department of Agriculture. The Economics of Food, Farming, Natural Resources, and Rural America-State Fact Sheets-Mississippi. Available online: http://www.ers.usda.gov/ StateFacts/MS.htm (accessed on 1 January 2010).

2. Kebede, H.; Fisher, D.K.; Sui, R.; Reddy, K.N. Irrigation methods and scheduling in the delta region of Mississippi: Current status and strategies to improve irrigation efficiency. Am. J. Plant Sci. 2014, 5, $2917-2923$. [CrossRef]

3. Feng, G.; Cobb, S.; Abdo, Z.; Fisher, D.K.; Ouyang, Y.; Adeli, A.; Jenkins, J. Trend analysis and forecast of precipitation, reference evapotranspiration and rainfall deficit in the Blackland Prairie of Eastern Mississippi. J. Appl. Meteorol. Climatol. 2016, 55, 1425-1439. [CrossRef]

4. Feng, G.; Ouyang, Y.; Adeli, A.; Read, J.; Jenkins, J. Rainwater deficit and irrigation demand for row crops in Mississippi Blackland Prairie. Soil Sci. Soc. Am. J. 2018, 82, 423-435. [CrossRef]

5. Tang, Q.; Feng, G.; Fisher, D.; Ouyang, Y.; Jenkins, J.; Adeli, A. Rain water deficit and irrigation demand of major row crops in the Mississippi Delta. Trans. ASABE 2017, 61, 927-935. [CrossRef]

6. Massey, J. Water-Conserving Irrigation Systems for Furrow and Flood Irrigated Crops in the Mississippi Delta. Available online: http://www.wrri.msstate.edu/pdf/2012_massey_pres.pdf (accessed on 20 November 2010).

7. Barlow, J.R.; Clark, B.R. Simulation of Water-Use Conservation Scenarios for the Mississippi Delta Using an Existing Regional Groundwater Flow Model; US Geological Survey Scientific Investigations Report; US Geological Survey: Reston, VA, USA, 2011; pp. 14-56.

8. Maupin, M.A.; Barber, N.L. Estimated Withdrawals from Principal Aquifers in the United States; USGS-U.S. Geological Survey: Reston, VA, USA, 2005. 
9. Clark, B.R.; Hart, R.M.; Gurdak, J.J. Groundwater Availability of the Mississippi Embayment; US Geological Survey Professional Paper 1785; US Geological Survey: Reston, VA, USA, 2011; pp. 62-72.

10. Steele, M.K.; Heffernan, J.B.; Bettez, N.; Cavender-Bares, J.; Groffman, P.M.; Grove, J.M.; Hall, S.; Hobbie, S.E.; Larson, K.; Morse, J.L.; et al. Convergent surface water distributions in US cities. Ecosystems 2014, 17, 685-697. [CrossRef]

11. Phillips, P. Overview of water availability in Mississippi. In Proceedings of the Annual Mississippi Water Resources Conference, Jackson, MS, USA, 6 April 2016.

12. Yazoo Mississippi Delta. Surface Water Irrigation: A Delta-Wide Option. Yazoo Mississippi Delta Joint Water Management District Annual Work Summary. Available online: http://www.ymd.org (accessed on 1 January 2016).

13. Stigter, T.Y.; Dill, A.C.; Ribeiro, L.; Reis, E. Impact of the shift from groundwater to surface water irrigation on aquifer dynamics and hydrochemistry in a semi-arid region in the south of Portugal. Agric. Water Manag. 2006, 85, 121-132. [CrossRef]

14. Gebreyohannes, T.; De Smedt, F.; Walraevens, K.; Gebresilassie, S.; Hussien, A.; Hagos, M.; Amare, K.; Deckers, J.; Gebrehiwot, K. Application of a spatially distributed water balance model for assessing surface water and groundwater resources in the Geba basin, Tigray, Ethiopia. J. Hydrol. 2013, 499, 110-123. [CrossRef]

15. Srivastava, P.; Gupta, A.K.; Kalin, L. An ecologically-sustainable surface water withdrawal framework for cropland irrigation: A case study in Alabama. Environ. Manag. 2010, 46, 302-313. [CrossRef]

16. Wu, X.; Zheng, Y.; Wu, B.; Tian, Y.; Han, F.; Zheng, C. Optimizing conjunctive use of surface water and groundwater for irrigation to address human-nature water conflicts: A surrogate modeling approach. Agric. Water Manag. 2016, 163, 380-392. [CrossRef]

17. Markstrom, S.L.; Niswonger, R.G.; Regan, R.S.; Prudic, D.E.; Barlow, P.M. GSFLOW-Coupled Ground-Water and Surface-Water FLOW Model Based on the Integration of the Precipitation-Runoff Modeling System (PRMS) and the Modular Ground-Water Flow Model; U.S. Geological Survey: Reston, VA, USA, 2008.

18. Regis, R.G.; Shoemaker, C.A. Combining radial basis function surrogates and dynamic coordinate search in high-dimensional expensive black-box optimization. Eng. Optim. 2013, 45, 529-555. [CrossRef]

19. Ouyang, Y.; Feng, G.; Read, J.J.; Leininger, T.D.; Jenkins, J.N. Estimating the ratio of pond size to irrigated soybean land in Mississippi: A case study. Water Sci. Technol. Water Supply 2013, 16, 1639-1647. [CrossRef]

20. Costa, A.C.; Bronstert, A.; Araujo, J.C. A channel transmission losses model for different dryland rivers. Hydrol. Earth Syst. Sci. 2012, 16, 1111-1135. [CrossRef]

21. Maheu, A.; Caissie, D.; Hilaire, A.; Jabi, N. River evaporation and corresponding heat fluxes in forested catchments. Hydrol. Process. 2014, 28, 5725-5738. [CrossRef]

22. Rao, N.H.; Sarma, P.B.S.; Chander, S. Optimal multicrop allocation of seasonal and intraseasonal irrigation water. Water Resour. Res. 1990, 26, 551-559. [CrossRef]

23. Arnold, J.G.; Moriasi, D.N.; Gassman, P.W.; Abbaspour, K.C.; White, M.J.; Srinivasan, R.; Santhi, C.; Harmel, R.D.; Van Griensven, A.; Van Liew, M.W.; et al. SWAT: Model use, calibration, and validation. Trans. ASABE 2012, 55, 1491-1508. [CrossRef]

24. Neitsch, S.L.; Arnold, J.G.; Kiniry, J.R.; Williams, J.R. Soil and Water Assessment Tool Theoretical Documentation Version 2009; Texas Water Resources Institute: College Station, TA, USA, 2011.

25. Barlow, J.R.; Coupe, R.H. Occurrence and Transport of Nitrogen in the Big Sunflower River, Northwestern Mississippi; US Geological Survey Annual Report; US Geological Survey: Reston, VA, USA, 2014.

26. Parajuli, P.B.; Jayakody, P. Big Sunflower River Watershed Assessment: Preliminary Report; Office of Agricultural Communications, Mississippi State University: Starkville, MS, USA, 2012.

27. Dakhlalla, A.O.; Parajuli, P.B.; Ouyang, Y.; Schmitz, D.W. Evaluating the impacts of crop rotations on groundwater storage and recharge in an agricultural watershed. Agric. Water Manag. 2016, 163, 332-343. [CrossRef]

28. Acreman, M.; Dunbar, M.; Hannaford, J.; Mountford, O.; Wood, P.; Holmes, N.; Cowx, I.; Noble, R.; Extence, C.; Aldrick, J. Developing environmental standards for abstractions from uk rivers to implement the eu water framework directive. Hydrol. Sci. J. 2008, 53, 1105-1120. [CrossRef]

29. Nikghalb, S.; Shokoohi, A.; Singh, V.P.; Yu, R. Ecological regime versus minimum environmental flow: Comparison of results for a river in a semi Mediterranean region. Water Resour. Manag. 2016, 30, 4969-4984. [CrossRef] 
30. Pastor, A.V.; Ludwig, F.; Biemans, H.; Hoff, H.; Kabat, P. Accounting for environmental flow requirements in global water assessments. Hydrol. Earth Syst. Sci. 2014, 18, 5041-5059. [CrossRef]

31. Ouyang, Y. A potential approach for low flow selection in water resource supply and management. J. Hydrol. 2012, 454, 56-63. [CrossRef]

32. Godinho, F.; Costa, S.; Pinheiro, P.; Reis, F.; Pinheiro, A. Integrated procedure for environmental flow assessment in rivers. Environ. Process. 2014, 1, 137-141. [CrossRef]

33. Yazoo Mississippi Delta. Yazoo Mississippi Delta Joint Water Management District Annual Work Summary. 2010. Available online: http://www.ymd.org (accessed on 1 January 2011).

34. Zhang, B.; Feng, G.; Read, J.J.; Kong, X.; Ouyang, Y.; Adeli, A.; Jenkins, J.N. Simulating soybean productivity under rainfed conditions for major soil types using APEX model in East Central Mississippi. Agric. Water Manag. 2016, 177, 379-391. [CrossRef]

35. Paz, J.O.; Fraisse, C.W.; Hatch, L.U.; Garcia, A.G.; Guerra, L.C.; Uryasev, O.; Hoogenboom, G. Development of an ENSO-based irrigation decision support tool for peanut production in the southeastern US. Comput. Electron. Agric. 2007, 55, 28-35. [CrossRef]

36. Batelis, S.C.; Nalbantis, I. Potential effects of forest fires on streamflow in the Enipeas River Basin, Thessaly, Greece. Environ. Process. 2014, 1, 73-85. [CrossRef]

37. Khanal, S.; Parajuli, P.B. Evaluating the impacts of forest clear cutting on water and sediment yields using SWAT in Mississippi. J. Water Resour. Prot. 2013, 5, 474-483. [CrossRef]

38. Wang, S.; Zhang, Z.; McVicar, T.R.; Guo, J.; Tang, Y.; Yao, A. Isolating the impacts of climate change and land use change on decadal streamflow variation: Assessing three complementary approaches. J. Hydrol. 2013, 507, 63-74. [CrossRef]

39. Foley, J.A.; DeFries, R.; Asner, G.P.; Barford, C.; Bonan, G.; Carpenter, S.R.; Chapin, F.S.; Coe, M.T.; Daily, G.C.; Gibbs, H.K.; et al. Global consequences of land use. Science 2005, 309, 570-574. [CrossRef]

40. Lotze-Campen, H.; Müller, C.; Bondeau, A.; Rost, S.; Popp, A.; Lucht, W. Global food demand, productivity growth, and the scarcity of land and water resouces: A spatially mathematical programming approach. Agric. Econ. 2008, 39, 325-338.

41. Scanlon, B.R.; Faunt, C.C.; Longuevergne, L.; Reedy, R.C.; Alley, W.M.; McGuire, V.L.; McMahon, P.B. Groundwater depletion and sustainability of irrigation in the US High Plains and Central Valley. Proc. Natl. Acad. Sci. USA 2012, 109, 9320-9325. [CrossRef]

42. Bredehoeft, J.D.; Young, R.A. Conjunctive use of groundwater and surface water for irrigated agriculture: Risk aversion. Water Resour. Res. 1983, 19, 1111-1121. [CrossRef]

43. Butler, J.J.; Whittemore, D.O.; Wilson, B.B.; Bohling, G.C. A new approach for assessing the future of aquifers supporting irrigated agriculture. Geophys. Res. Lett. 2016, 43, 2004-2010. [CrossRef] 